Available online at: $\mathrm{http}: / /$ proceeding.rsfpress.com/index.php/pss/index

LPPM UPN “Veteran” Yogyakarta Conference Series

Proceeding on Political and Social Science (PSS)

Volume 1 Number 1 (2020): 238-247

\title{
The Role of Transformational Leadership in Community Empowerment in the Digital Business Era
}

\author{
Hastho Joko Nur Utomo, Eny Endah Pujiastuti, Rifki Indra Perwira, Heru C. \\ Rustamadji
}

\begin{abstract}
Universitas Pembangunan Nasional Veteran Yogyakarta
Email address hastho.joko@upnyk.ac.id; Email address eny.endahp@upnyk.ac.id,Email address rifki@upnyk.ac.id, Email address herucs@upnyk.ac.id
\end{abstract}

\begin{abstract}
The role of transformational leadership in digital business still requires more in-depth research. Therefore, this study aims to analyze the role of transformational leadership in the recovery of the home industry in the region or society based on community empowerment and digital business. This study used a qualitative approach using observation and an in-depth interviewer. This research was conducted in a public organization, namely $R W 13$ Kelurahan Panembahan, Kraton DIY District. The results showed that the role of leadership in running and supporting public organizations $(R W)$ through digital business transitions is very important to restore the economy of society in general and the home industry in particular. The contribution of this research is to enrich the literature that examines transformational leadership in the context of digital business and community empowerment. Suggestions for further research are to do more research on transformational leadership in digital business development for both business organizations and public organizations.
\end{abstract}

Keywords: Transformational leadership, Community development, Digital Business, Market place, Story Marketing

\section{INTRODUCTION}

This is an open access article under the CC-BY-NC license.

The phenomenon of the COVID 19 outbreak that is currently occurring has an impact on all areas of life for the world community, including the economy and business. The downturn in business, especially home businesses (small businesses), has resulted in a decrease in income and a decrease in people's purchasing power. However, there are environmental conditions that can provide benefits at this time, namely technological developments such as information technology (internet). The development of information technology (internet) can be used to improve the economy, especially small businesses (home industries). This has been conveyed by Larjovuori, Bordi, and Tammi (2018) that the development and 
implementation of information and communication technology (ICT) has a major impact on business and life as a whole.

Therefore, the home industry as one of the economic pillars of the people living in regional areas must immediately find a solution so that it will recover as before. One of the strategies used to improve home industries is to use information and communication technology (ICT) and community empowerment. Home industry recovery can be carried out jointly in a certain regional environment with the community empowerment method. This community-based economic recovery will occur quickly if the regional leaders participate actively in community empowerment. The optimal role of local regional leaders is highly expected.

Based on previous research studies from Larjovuori et al. (2018) note that there is four main leadership focuses on digital business transformation: strategic vision and action, leading cultural change, supporters, and networks. This research was conducted in service companies and the role of leadership in digital business transformation is a topical issue that still requires more in-depth research. Therefore, the role of transformational leadership in digital business is a motivation for conducting this research. The study of the role of transformational leadership in restoring the home industry in the region or community based on community empowerment and digital business is a novelty in this research. Another novelty is the role of transformational leadership roles applied in public organizations.

Specifically, the problem formulation, as well as the purpose of this study, is to analyze the role of transformational leadership in the recovery of the home industry in the region or society based on community empowerment and digital business. In addition, this research will deepen the use of transformational leadership theory and community empowerment theory in developing community business (home industry). Thus, it can be said that transformational leadership is the foundation for the creation of attitudes and behavior of the community to jointly restore business and the community's economy. The literature review on transformational leadership in the context of digital business is still in its early stages, so this research can enrich the literature that examines transformational leadership in the context of digital business.

\section{LITERATURE REVIEW}

\section{Digital Business}

Digitalization is the use of digital technology to change business models and provide new benefits and opportunities to increase added value. This is the process of moving to digital business (Gartner, 2016). The process of transforming digital business services, for example, transactions between digital businesses, digital customer access, and digital core services (Saldanha, Kathuria, Khuntia, Konsynski and Rojas, 2017). "Digital" in digital business models can be seen as resource optimization enhanced through digital technology, such as Uber-like mobility sharing schemes or Software as a Service (SaaS), interacting between entities and systems (Li.; Badr, and Biennier, 2012; Bharadwaj .; El Sawy, Pavlou, and Venkatraman, 2013; Planning, 2013). Business is called digital if changes in digital technology trigger fundamental changes in the way of doing business and have an impact on the income generated (Veit; Clemon .; Benlian .; Buxmann .; Hess .; Spann .; Kundisch .; 
Leimeister, and Loos, 2014). This change is exemplified in the difference between place (i.e., before the internet business model) and space (i.e., the digital world) (Weill and Woerner, 2013). "It's a tangible, product-based, customer transaction-oriented world. Today, many industries - all moving at different speeds - are turning to a digital, intangible, more service-based, and customer experience-oriented world (Weill and Woerner, 2013). According to Weill and Woerner (2013), three components are central to the digital business value proposition, namely: platform, content, and experience. The main elements of digital according to Westerman et al (2014) are business transformation: transforming customer experience (customer understanding, top-line growth, customer touchpoints); operational processes (digitization, worker enablement, and performance management); and business models (digitally modified businesses, new digital businesses, and digital business globalization).

\section{Community development}

Community development fosters a high sense of togetherness because every member of the community works together to improve welfare (Kenny, 2011). The role of a citizen can be carried out in four ways. First, most maintain a relationship between 'givers' and recipients of welfare under the name of 'civil virtue'. The second type of active citizenship is 'individual self-help or do it yourself' (Kenny, 2011). Third, it could take the form of 'defensive opposition', where citizens can challenge certain policies and resist changes to existing relationships or assets; However, power relations were not challenged. The fourth type of citizenship is the ideal version of 'visionary active citizenship'.

\section{Transformation Leadership}

Transformational leadership theory was first proposed by Burns (1978) to distinguish between leaders who have a strong motivational relationship with their followers and subordinates and who are broadly focused on exchanges with transformational leadership interactions to create results. Transformational leadership is a leadership style in which the leader inspires followers to go beyond their interests for the benefit of the organization; leaders can have a profound and desirable effect on followers to make the changes needed (Robbins, 2003). Transformational leadership is a conscious, moral, and spiritual process that provides an equal pattern of power relations between leaders and followers to achieve collective goals or real transformation. Transformational leadership consists of 4 main dimensions: The influence of idealized influence, inspirational motivation, intellectual stimulation, and personal judgment (Hoffmeister, Alyssa, Gibbons, Stefanie, Johnson, Konstantin, Cigularov, and Chen (2014).

Currently, most research on transformational leadership uses explanatory research, examining the relationship between variables, for example, research was to examine how transformational leaders boost their followers' innovative work behavior through trust in a leader, empowerment, and work engagement (Hui Li, 2019). There is little research on transformational leadership using qualitative descriptive types, for example, research was to describe the concept of transformational leadership as a hallmark of a future digital business leader (Junita, 2019). So this research will add to the empirical study using a phenomenological approach, especially in the COVID-19 pandemic era. 


\section{RESEARCH METHODOLOGY}

This research study is descriptive qualitative. The purpose of this study was to analyze the role of transformational leadership in restoring the home industry based on community empowerment and digital business. The researcher acts as a research instrument. Data were collected through observation, focus group discussions, and in-depth interviews with informants. Researchers try to see the social world from the point of view of the Chairman of RW 13 Kraton. Various aspects and practices of transformational leadership are explored in-depth in this study, namely the leadership of a community leader (Head of RW 13 Panembahan, Kraton, DIY). The researcher formulated a question about how the leadership practice of the chairman of RW 13 Kraton since the COVID-19 pandemic, then triangulated the local community members. Then the interview results were analyzed. Data analysis began with transcribing the interviews, reading them over and over again, and drawing tentative conclusions about the relationships between categories.

\section{FINDING AND DISCUSSION}

In the COVID 19 pandemic situation, leaders have a desire to restore the economy of the people in their region, especially restoring home industries. This is because small businesses (home industries) become more financially vulnerable during and after a disaster. The leader plans a strategy for recovery by involving the people in his area. Leaders do not change the type of business the community does with their home industry but helps to market home industrial products to the public. Products that are marketed to people in the area are intended to meet the needs of the community itself and the people around the area. This policy was taken by RW leaders because at the time of the pandemic, people could not freely leave the house even though they only met their daily needs. So this activity is from the community and back for the community.

Another step taken is to take advantage of information and communication technology to restore the home industry. The leader encourages the home industry as a digital business by developing a marketplace as an area for marketing their products or using other social media such as Facebook and Whatsapp. Leaders provide understanding and motivation to home industries to take advantage of technology in their business. The leader chooses simple business digital media according to the ability of the community. Leaders involve community members who already have businesses and can still survive this pandemic to help other home industries survive and thrive.

In empowering the community with their digital business, regional leaders collaborate with universities (UPN "Veteran" Yogyakarta). The collaboration is carried out with lecturers who have expertise in the fields of business and information technology. Collaboration in developing technology-based marketing media (marketplace), creating story marketing, promotional strategies, and so on. With this cooperation, the economic recovery of the community will be realized quickly, although there are many obstacles faced in implementing it. As for some of the results of digital business-based community empowerment activities as follows: Seruni shop as one of the home industries opened by the RW chairman as a means to market community business results and provide sales locations 
so that people do not spend money on renting a place, online promotions can be done by using Facebook media with the address https://m.facebook.com/kedaiserunih/, promotion via the website at https://kedaiserunih20.000webhostapp.com/, media Instagram with the address https://www.instagram.com/kedaiserunih /. The choice of social media was made because the intended consumers or target market were the millennial generations. This millennial generation can quickly follow the development of information technology. The accuracy in selecting the media will determine the success of its marketing.

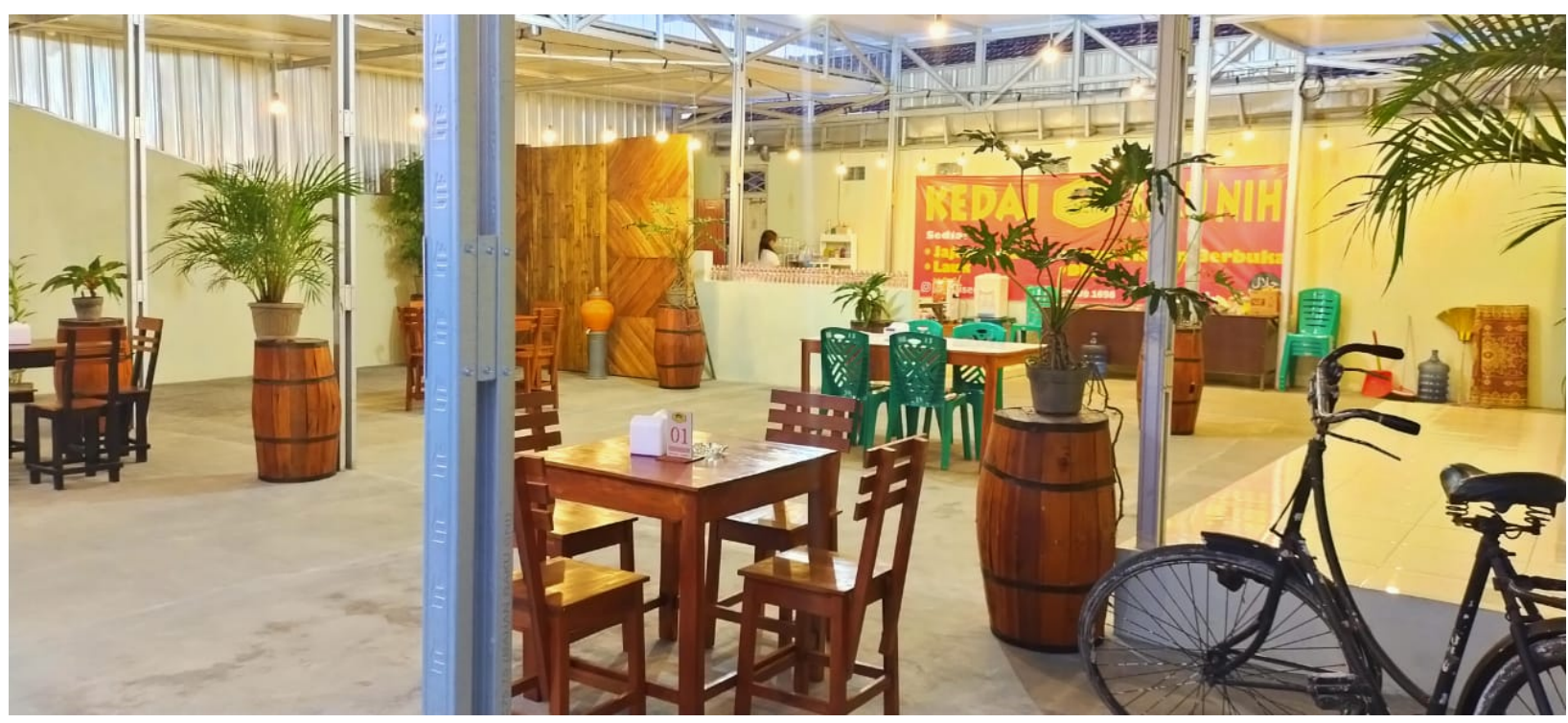

Figure 1: Kedai Seruni

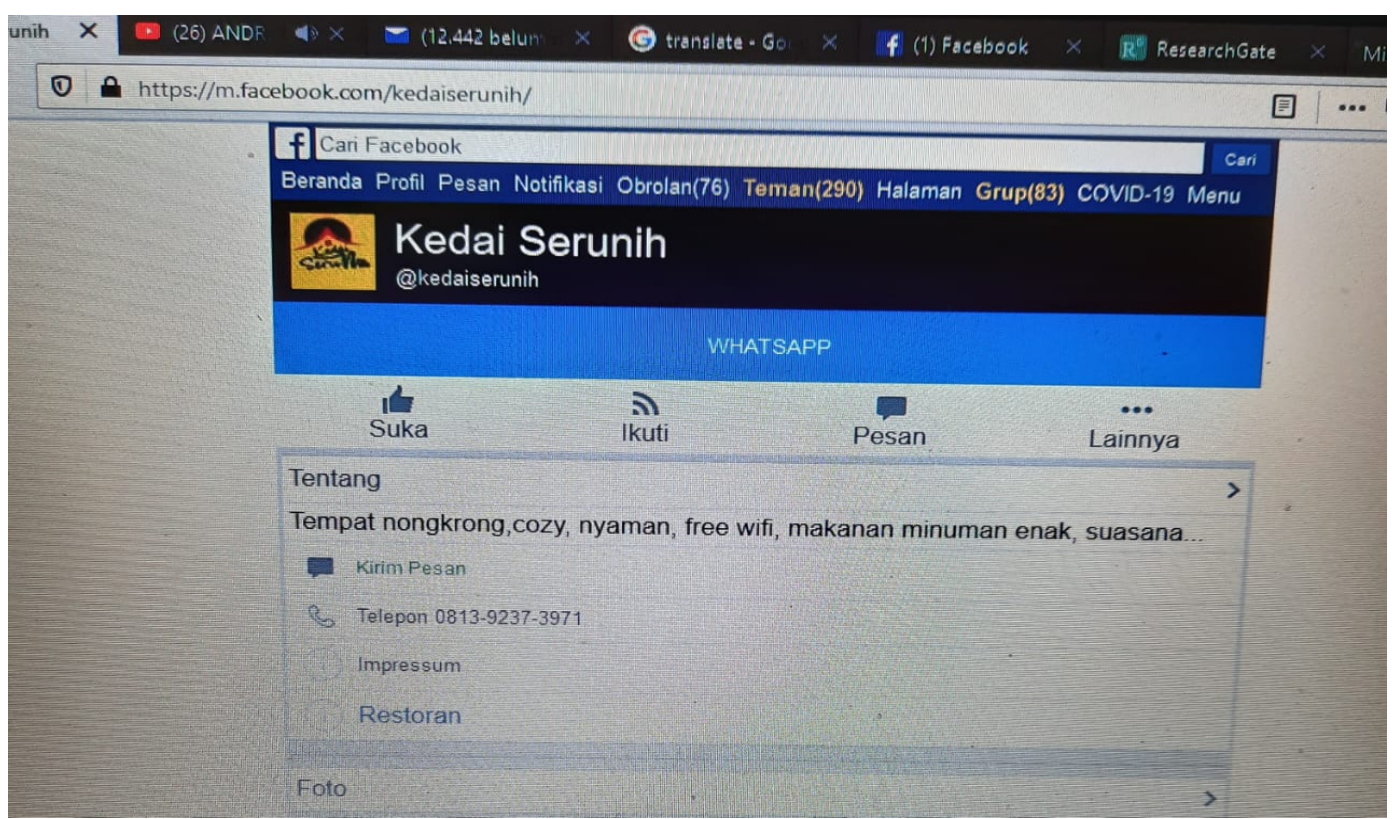

Figure 2: Online promotion on Facebook 
The Role of Transformational Leadership in Community Empowerment in the Digital Business Era Hastho Joko Nur Utomo, Eny Endah Pujiastuti, Rifki Indra Perwira, Heru C.Rustamadji

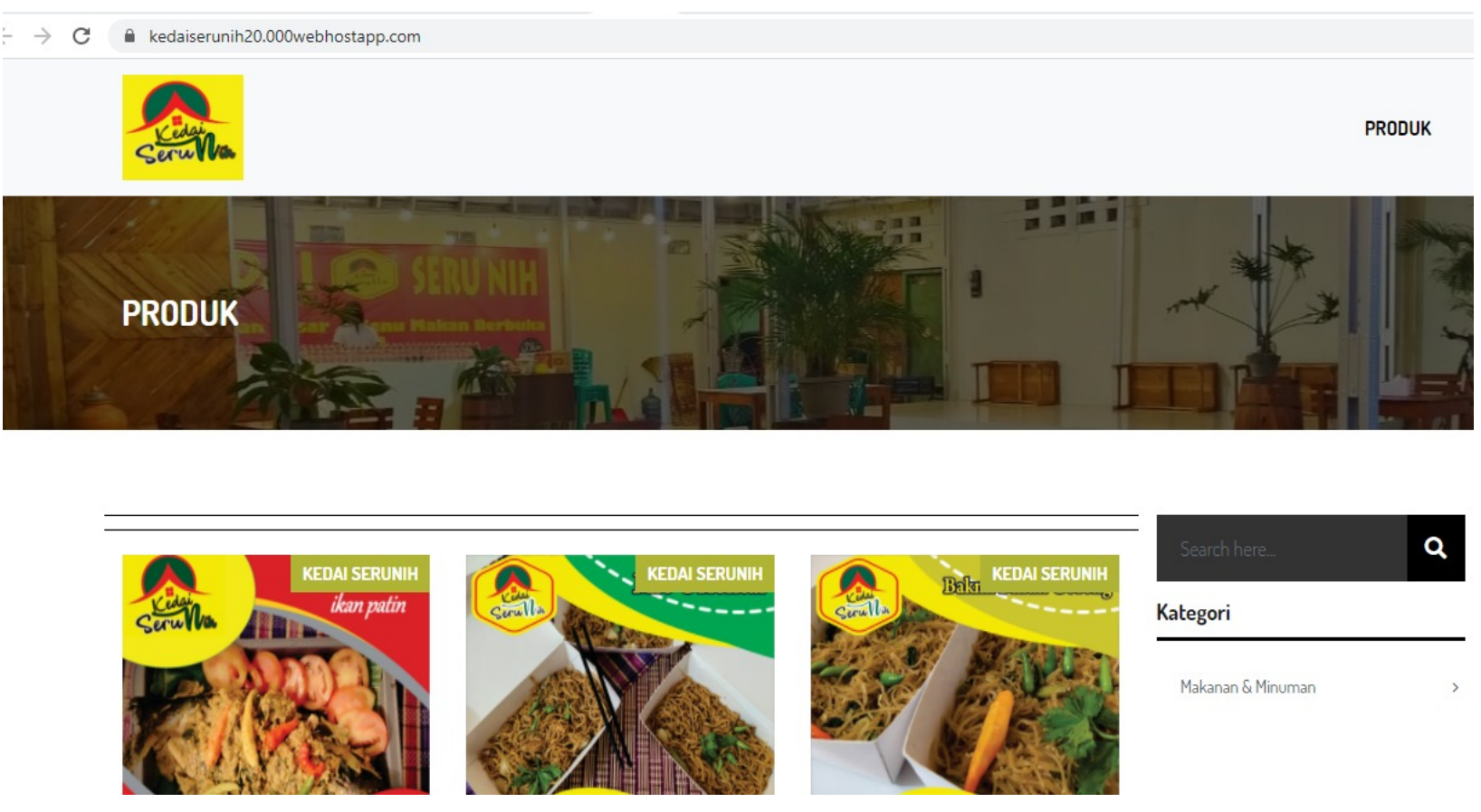

Figure 3: Media Promotion in Website 


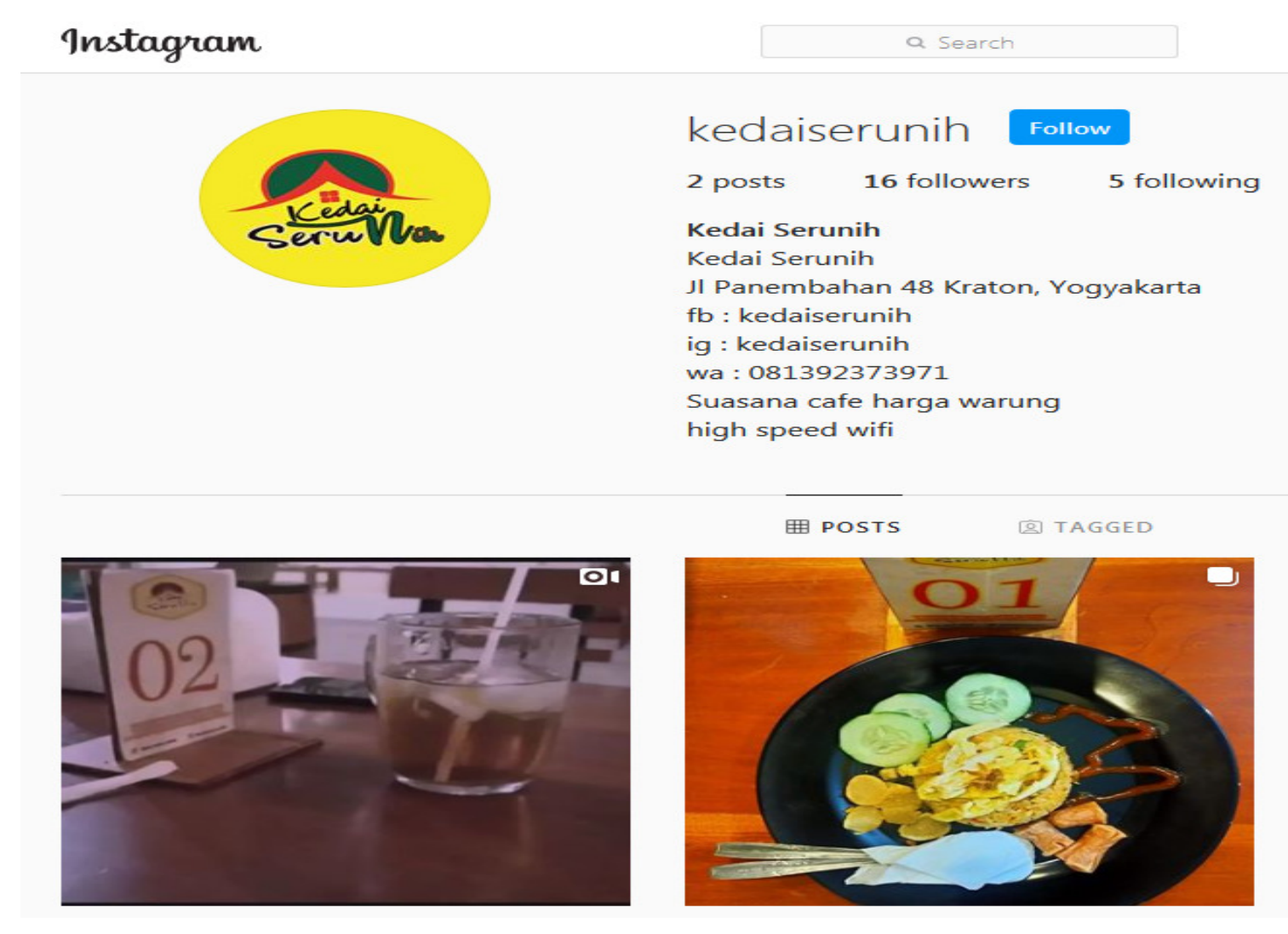

Figure 4: Media Promotion in Instagram

Based on the analysis of the data obtained, it is known that the leaders of public organizations (RW heads) in community empowerment use transformational leadership styles. Local leaders have an important role to play in economic response and recovery. This is because in carrying out its policies there are characteristics of transformational leadership in digital business as stated by Larjovuori et al. (2018). The main leadership focus of digital business transformation is owned by leaders of public organizations (RW heads) such as strategic vision and action, leading cultural change, enabling, and leading networks. Leaders are very involved in the digital transformation of business, this shows that a transformational style requires increased managerial involvement and enthusiasm for change (Holten and Brenner, 2015)

The use of a transformational leadership style is the right type of leadership style in the conditions of the COVID 19 pandemic because leaders must have the ability to adopt strategies that will positively influence the digital transformation process. The transformational leadership style is a leadership style that is in tune with the needs of today's society. The right leadership style can make the transition from a traditional business to a digital business easier. Other roles of local leaders in economic recovery are Inspiration for Community Recovery, Spokesperson, Analyst, Visionary / Catalyst, Gap Filler, Connector / Advocate, Project Manager.

The leader gives an example of implementing policies made such as a leader opening a business other than for himself as well as providing sales location facilities for people in 
their area. Leaders not only tell the community to change, but the leaders themselves also experience changes in line with other changes in society. Transformational leaders can develop by setting an example for others to follow, inspiring others to succeed, sharing a vision, and empowering creativity (Holten and Brenner, 2015). Transformational leaders can motivate others and creativity ((Baskarada, Watson, and Cromarty, 2016).

One of the goals of a leader in setting an example is to ensure that the strategy he chooses is the right one. The appropriateness of the strategy is chosen to ensure that the organization can succeed with the capabilities of its new technology (Kane, Palmer, Phillips, Kiron, and Buckley, 2015). The strategy is chosen, namely, digital business is the right strategy during the COVID 19 pandemic conditions (as a threat) by utilizing information and communication technology (as an opportunity). Digitalization is a process that affects almost all organizations. Therefore, all leaders need to understand the implications for organizations, as well as society. Digitalization requires new skills and competencies, new forms of leadership, and new organizational capabilities (Kohnke, 2017). The leader knows that most people do not know about digital business, so the leader develops networks with universities. Networks are developed to acquire new skills and competencies, new forms of leadership, and new organizational capabilities.

Digital business strategy requires cultural changes from society, especially in managing their home industry. Therefore, leaders must provide understanding and understanding to the community as home industry players about digital business and the benefits of digital business. As we know, the difficulty in public organizations and society is to convince people of the goodness of the strategy in the economic recovery of society. This is as stated by Dahlström, Desmet, and Singer (2017), namely digital transformation requires the following elements: identification of the future direction of the business; identification of leaders to drive transformation; convince key stakeholders that transformation is a good idea; determine how organizations can compete for positions in the digital age; determine how decisions should be made during transformation; obtaining funds to achieve transformation goals; and identify areas where the organization can succeed with these efforts and achieve its goals Effectively.

Transformational leaders change their organizational culture by empowering the community. Community empowerment, which is meant in transformational leadership, is to encourage people to develop digital to meet the needs of the community itself and to raise awareness from people who can manage businesses to help other communities develop their businesses. Community empowerment allows people to mobilize and build assets to improve their quality of life sustainably. The goal of empowerment in economic recovery is to plan to change the situation of decreasing income. Community empowerment is the right way to restore the economy because it is a process that allows people to adapt to challenges (decreased income due to the COVID 19 pandemic) and opportunities (developments in information and communication technology).

\section{CONCLUSION AND FURTHER RESEARCH}

The conclusion that can be drawn is that the role of leadership in running and supporting public organizations (RW) through digital business transitions is very important to restore 
the economy of the community in general and the home industry in particular. Transformational leaders must have a clear vision of the goals of digitizing the home industry (their business) and the actions needed to make it happen. Also, transformational leaders in digital business development in society have the ability to develop networks, have a willingness to develop competencies and skills, dare to take a stand to change organizational culture, set an example for society.

Transformational leaders change their organizational culture by empowering people. Community empowerment, which is meant in transformational leadership, is to encourage people to develop digital to meet the needs of the community itself and to raise awareness from people who can manage businesses to help other communities develop their businesses. The transformational leadership strategy will influence and impact the process of changing the manual business to a comprehensive digital platform, in the long term.

Suggestions for further research are to do more research on transformational leadership in digital business development for both business organizations and public organizations. Indepth research needs to be done to enrich the literature on leadership styles and digital business because in the future there will be many business activities that use information and communication technology.

\section{REFERENCES}

Baškarada, S., Watson, J., \& Cromarty, J. (2017). Balancing transactional and transformational leadership. International Journal of Organizational Analysis, 25(3), 506515.

Bharadwaj, A.; El Sawy, O.A.; Pavlou, P.; Venkatraman, N. Digital business strategy: Toward the next generation of insights.MIS Q.2013,37, 471-482

Dahlström, P., Desmet, D., \& Singer, M. (2017). The seven decisions that matter in a digital transformation: a CEO's guide to reinvention. Digital McKinsey article (Feb 2017).

Holten, A. L., \& Brenner, S. O. (2015). Leadership style and the process of organizational change. Leadership \& Organization Development Journal, 36(1), 2-16.

Hoffmeister, A., Alyssa, M., Gibbons, A., Stefanie, K., Johnson, B., Konstantin, P., Cigularov, C., \& Chen P., Y. (2014). The differential effects of transformational leadership facets on employee safety. p. 69

Junita, I (2019), Transformational Leadership in Digital Era: Analysis of Nadiem Makarim (Founder of GO-JEK Indonesia) Leadership Figure, IJBE (Integrated Journal of Business and Economics), pp 80-92

Kane, G. C., Palmer, D., Phillips, A. N., Kiron, D., \& Buckley, N. (2015). Strategy, not technology, drives digital transformation. MIT Sloan Management Review and Deloitte University Press, 14. Retrieved from https://sloanreview.mit.edu/projects/strategydrives-digital-transformation/

Ke nny, S. (2011). Developing communities for the future (4th ed.). South Melbourne, Australia: Cengage Learning

Larjovuori, Riitta-Liisa; Bordi, Laura and Tammi, Kirsi Heikkilä, 2018, Leadership in the digital business transformation, Association for Computing Machinery. ACM I 
Li, W.; Badr, Y.; Biennier, F. (2012), Digital ecosystems: Challenges and prospects. In Proceedings of the InternationalConference on Management of Emergent Digital EcoSystems, Addis Ababa, Ethiopia, 28-31 October 2012; ACM: New York, NY, USA, pp. 117-122.22

Li, H; Sajjad N; Wang Q; Ali, MA; Khaqan Z, Amina S; (2019), Influence of Transformational Leadership on Employees' Innovative Work Behavior in Sustainable Organizations: Test of Mediation and Moderation Processes, mdpi.com, journal sustainability; pp 1-21

O. Kohnke.2017. It's not just about technology: The people side of digitization. In G. Oswald and M. Kleinemeier (Eds.) Shaping the Digital Enterprise, 69-91. Springer, Waldorf

Gartner.2016. IT Glossary. https://www.gartner.com/it-glossary/d.

Planing, P. Will digital boost circular? Evaluating the impact of the digital transformation on the shift towards a circular economy. Int. J. Manag. Cases2017,19, 22-31

Robbins SP (2003) Organization behavior (8th ed) New Jersey: Prentice-Hall, Upper Saddle River.

T. J. V. Saldanha, A. Kathuria, J. Khuntia, B. Konsynski,andM. A. Rojas.2017. Leveraging Digitalization of Services for Performance: Evidence from the Credit Union Industry. International Conference on Information Systems, ICIS Proceedings(2017).[6]

G. Westerman, D. Bonnet, and A. McAfee. 2014. Leading Digital: Turning Technology into Business Transformation. Harvard Business Publishing, Brighton, MA

Weill, P.; Woerner, S.L. Optimizing your digital business model.MIT Sloan Manag. Rev.2013,54, 71-78.

Veit, D.; Clemons, E.; Benlian, A.; Buxmann, P.; Hess, T.; Spann, M.; Kundisch, D.; Leimeister, J.M.; Loos, P.Business Models - An Information Systems Research Agenda.Bus. Inf. Syst. Eng.2014,6, 45-53. 